\title{
マングローブ植林実証試験地からのメタンと一酸化二窒素放出量
}

\section{Estimation of Methane and Nitrous oxide emission from mangrove plantation ecosystem}

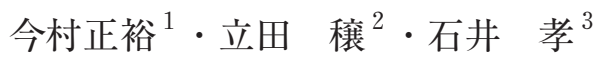 \\ Masahiro IMAMURA, Yutaka TATEDA and Takashi ISHII
}

\begin{abstract}
The emission of $\mathrm{CH}_{4}$ and $\mathrm{N}_{2} \mathrm{O}$ from mangrove plantation area were important for evaluation of carbon stock in an implementation of a mangrove CDM project. Emission rate of $\mathrm{CH}_{4}$ and $\mathrm{N}_{2} \mathrm{O}$ from non-mangrove ecosystem (wetland and fresh water et. al) for mangrove plantation area were from -90 to $36648 \mu \mathrm{mol} \mathrm{CH}_{4} \mathrm{~m}^{-2}$ day $^{-1}$, from -41 to $499 \mu \mathrm{mol}$ $\mathrm{N}_{2} \mathrm{O} \mathrm{m}{ }^{-2}$ day ${ }^{-1}$. Discrepancies exist in the emission of $\mathrm{CH}_{4}$ and $\mathrm{N}_{2} \mathrm{O}$ obtained from the other ecosystem due to environmental condition (high loading and salinity). We estimated emission of $\mathrm{CH}_{4}$ and $\mathrm{N}_{2} \mathrm{O}$ from our planted mangrove area in Vietnam by observed data, which suggests that total emission of $\mathrm{CH}_{4}$ and $\mathrm{N}_{2} \mathrm{O}$ from mangrove ecosystem was approximately $10-20 \%$ of total carbon stock in mangrove forest over 21 years integration from a mangrove plantation.
\end{abstract}

\section{1.はじめに}

1997年の国連気候変動枠組条約第3 回締約国会議にお いて策定された「京都議定書」では, クリーン開発メカ ニズム（以下 CDMと略す）を利用した途上国における 植林・再植林による $\mathrm{CO}_{2}$ 吸収源確保事業により創出され る $\mathrm{CO}_{2}$ 削減が, 先進国の温室効果ガス排出削減量として 認められた。これらの植林・再植林・（土地利用管理） 活動に基づく各国の国内 $\mathrm{CO}_{2}$ 削減（固定・吸収）量の評 価方法については，気候変動に関する政府間パネル（以 下IPCC と略す）により，「土地利用，土地利用変化及び 林業」に伴う温室効果ガス排出・吸収量推計に関するグ ッドプラクテイスガイダンス（良好手法指針）が作成さ れている (IPCC，2003）。CDMを利用した植林・再植林 事業における $\mathrm{CO}_{2}$ 固定量評価法もこれに準ずるとされる が，具体的な評価法については，個別プロジェクトにお いて検討・認証される。

熱帯・覀熱帯に位置する発展途上国において，主に防 風・防波林として植林されてきたマングローブは，熱帯 雨林と並んで, その高い生産力とマングローブ植林によ り形成される泥炭層の有機炭素貯蔵能力により, マング ローブ生態系全体が大きな $\mathrm{CO}_{2}$ 吸収と貯蔵能力を有する 事が科学的に示され (Alongiら，2005；立田ら，2009； 石井ら，2009), 熱帯・亜熱帯域における CDM植林・再 植林事業による地球温暖化ガス吸収・放出抑制方策とし ての有効性が期待されている.

新規植林・再植林により $\mathrm{CO}_{2}$ 吸収量を増加させる $\mathrm{CDM}$ プロジェクトの実施ルールは2003年 12 月に開催した

$\begin{array}{llll}1 & \text { 正会員 } & \text { 工博 } & \text { (財) 電力中央研究所 } \\ 2 & \text { 非会員 } & \text { 農博 } & \text { (財) 電力中央研究所 } \\ 3 & \text { 正会員 } & \text { 工博 } & \text { (財) 電力中央研究所 }\end{array}$

COP9で決定され，プロジェクトの申請受付が開始され た.マングローブ植林については，「湿地における小規 模 CDM植林プロジェクト活動のための簡素化したベー スライン及びモニタリング方法論」が簡素化された方法 論として利用可能である。しかしながら，小規模 CDM の簡素化方法論（林野庁 HP）では，マングローブ植林プ ロジェクト事業によって堆積物の化学組成は変化しない という前提条件のもと, $\mathrm{CO}_{2}$ よりも地球温暖化係数 (GWP值) の值が高い $\mathrm{CO}_{2}$ 以外の温室効果ガス $\left(\mathrm{CH}_{4} \cdot\right.$ $\left.\mathrm{N}_{2} \mathrm{O}\right)$ の発生は0として考慮されていない.

当所では，これまでマングローブ生態系から発生する $\mathrm{N}_{2} \mathrm{O}$ の測定評価技術を開発し，その発生量がマングロー ブのない前面（例えば干潟）からの発生量より高くなる 可能性を示している (今村ら，2002）。植林直後は林の 生残率問題が残るものの, 4-5 年程度経過すると林内の 根元では有機物の捕捉能力が高まりその量も増加する. つまり, 堆積物中のその他温室効果ガス放出能力も高く なると推察される。マングローブが成長し $\mathrm{CO}_{2}$ 吸収能力 が小さくなり炭素貯蔵量が安定した場合でも，その他温 室効果ガス放出は継続されることから, その検討が重要 であると考える。

そこで, 著者らはモニタリング事業やベースライン (植林事業が実際されなかった場合の温室効果ガス放出 量）測定時における活用を目指し，マングローブ植林に よる温室効果ガスの削減量を正確に見積るために重要 な, $\mathrm{CH}_{4} \cdot \mathrm{N}_{2} \mathrm{O}$ の放出速度について, 環境条件別にその ベースライン測定值を整理するとともに，マングローブ 植林実証試験地からのその他温室効果ガスの放出量を推 定し, 林炭素固定量からどの程度相殺されてしまうのか について検討した。 
表-1 マングローブのない地域からの放出速度

\begin{tabular}{c|c|c|c}
\hline \multirow{2}{*}{} & \multicolumn{3}{|c}{ ベースライン放出速度 $\left(\mu \mathrm{mol} \mathrm{m}^{-2} \mathrm{day}^{-1}\right)$} \\
\cline { 2 - 4 } & 最大值 & 最小值 & $\begin{array}{c}\text { 平均值 } \\
(\mathrm{n} \text { : サンプル数 })\end{array}$ \\
\hline $\mathrm{CH}_{4}$ & 36648 & -90 & $199(\mathrm{n}=9)$ \\
\hline $\mathrm{N}_{2} \mathrm{O}$ & 499 & -41 & $192(\mathrm{n}=13)$ \\
\hline
\end{tabular}

\section{2. ベースラインとしての $\mathrm{CH}_{4} \cdot \mathrm{N}_{2} \mathrm{O}$ 放出速度}

マングローブ植林はその多くが沿岸干潟にて実施され ることが多いが, 周辺環境や陸上からの栄養供給状態, さらに河川・沿岸の流動による堆積物の移動変化によ り，堆積物中の物質循環は大きく異なるとことが予想さ れる．植林事業では植林前後における温暖化ガス評価が 重要であり, 植林前にその土地からどの程度の温暖化ガ スが放出されているかはベースライン值として事業計画 の上で重要な課題である。 そこで, マングローブのない 沿岸生態系を対象に既存の文献を整理した（Tateda, 2005).

$\mathrm{CH}_{4}$ は嫌気的条件下の堆積物中有機物分解における最 終段階反応から発生する（Prieme, 1994）ことが知られて いるが, その反応にはエネルギー段階的に一つ前の反応 物質である硫酸・硫化物の存在が大きく影響し, 低硫酸 イオンの環境（硫酸還元活性の低い）で有機物供給速度 が大きな場では $\mathrm{CH}_{4}$ の発生量が高くなる可能性がある. この低硫酸還元は, 淡水域で顕著であるが, Ginaniら （1996）は沿岸域における発生がないわけではなく，放 出傾向にある地域としては汽水や海水等が滞留している ような場所が多いことを指摘している。 また，インドな どでは栄養塩や有機物の負荷が高い場所で, $\mathrm{CH}_{4}$ 生成お よび発生量が高いといった報告もある（Mukhopadhyay ら, 2002).

一方, $\mathrm{N}_{2} \mathrm{O}$ は窒素循環過程の中間生成物であり, 酸 化・還元が共存する場で発生が顕著である. 特に流入負 荷等の人為的な要因により発生量が決定している場合が しばしばある. Seirzinger（1998）によれば， $\mathrm{N}_{2} \mathrm{O}$ の発生 量は全球で約 $1.9 \mathrm{TgNyear}^{-1}$ と推定され, その約 $11 \%$ が河 川・沿岸地域由来, さらにその $90 \%$ は中国および東南ア ジアがソースである可能性が指摘されている. そのため, 生産性の高いマングローブ林内および前面の干潟は, 有 機物量も豊富であり底生生物も多いことから $\mathrm{N}_{2} \mathrm{O}$ 生成が 起こりやすく, 植林されたマングローブ域が $\mathrm{N}_{2} \mathrm{O}$ 放出域 となる可能性は高い. さらに, Eihner（1990）は, 陸上 の窒素肥料散布による発生を指摘している. 窒素肥料の 主成分はアンモニアであり, 水田や森林管理のために散 布される. 栄養分として植物に利用されなかった窒素分 が, 堆積物中にて還元され $\mathrm{N}_{2} \mathrm{O}$ として発生することがあ

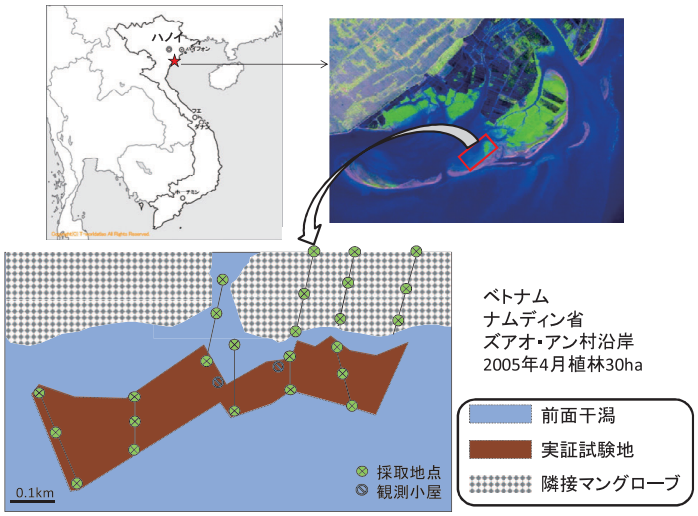

図-1 植林実証試験地および観測点

る.これは, 淡水域や河川においても顕著であり, 高負 荷の窒素排水があるような場では, $\mathrm{N}_{2} \mathrm{O}$ 放出速度は高い 值となる（Michael, 1994 ; Mander ら, 2005 ; Miltonら， 2002).

このように, $\mathrm{CH}_{4}$ と $\mathrm{N}_{2} \mathrm{O}$ の放出には有機物と栄養塩の 供給が大きなカギをにぎっている．既存のデー夕を整理 した結果を表-1に示す.マングローブの生育していない 生態系においては，こういった負荷が高い場所で，ガス 発生速度が大きくなる傾向があり, 環境条件によってば らつきも大きい. どういった場所に植林するかによって は, ベースライン值は大きく異なり, 植林予定域の環境 を考慮したり, 事前の現地調査を実施したりすることが 必要と考える。

\section{3. 調查地点および分析方法}

マングローブ植林実証試験地は, ベトナムのナムディ ン省南東部のズアオ・アン村沿岸, 60ha 既植林地の前面 海域北側約 $30 \mathrm{ha}$ （北東方向約 $300 \mathrm{~m}$, 南東方向 $1000 \mathrm{~m}$ ）の 干潟に,メヒルギの胎生種子（全長約 $25 \mathrm{~cm}$ ) を $70 \mathrm{~cm}$ 間 隔で植林した，植林は，2005年4月14日ー16日に，ズア オ・アン村民の手で行われた（図-1）.

調査は，1）植林予定地前面の干潟，2）植林後のマン グローブ域，3）隣接する成熟マングローブ林（5～9年

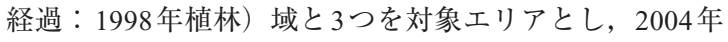
〜2007年にかけ年 1 回（4月〜 6月時期）実施した.

ガス放出速度の観測は, いくつかの方法が提案されて いるが, 統一されたものはない.一般的にはチャンバー を堆積物上面に覆い, チャンバー内ガス濃度の時間的な 変化から放出速度を測定する方法を用いる. 今回は, 現 地でのガス分析技術がないこと, ガス態のサンプルが輸 送時に変化するであろうことを考慮し，堆積物に含まれ るガス濃度を調べることとした。 バイアル瓶に堆積物表 層泥を適量（5 20g）採取し, 微生物によるガス組成の 変化を防ぐために採取後直ちに $\mathrm{HgCl}_{2}$ （50\%Sat.）を $50 \mu \mathrm{l}$ 
添加し, 冷凍保存し持ち帰ることで, 現場に近い堆積物 ガス含有量を把握できると考えた.

ガス濃度測定には, $\mathrm{CH}_{4}$ はFIDガスクロ（YANAKO社 製, ）， $\mathrm{N}_{2} \mathrm{O}$ は ECD ガスクロ（島津ECD GC-8A，63NiECD-GC）を用い, ヘッドスペース法によりバイアル瓶 気相中のガス濃度を測定し, 湿泥当たりのガス含有量を 算出した. なお, 分析前に $40{ }^{\circ} \mathrm{C}$ の恒温水槽でバイアル瓶 を約 4 時間振とうさせた. 瓶内の気相中ガスは湿泥溶液 中のガスと熱力学的平衡状態であると仮定し, 溶液中の ガス量を気相中ガス分析結果から溶液中濃度を算出し堆 積物中のガス濃度とした。

\section{4. 植林実証試験地の $\mathrm{CH}_{4} \cdot \mathrm{N}_{2} \mathrm{O}$ ガス含有量}

現地調査から得られた堆積物中の $\mathrm{CH}_{4} \cdot \mathrm{N}_{2} \mathrm{O}$ ガス含有 量の結果を表-2, 3 に示す. $\mathrm{N}_{2} \mathrm{O}$ については, 季節（雨 季・乾季) に応じてばらつきが見られた. 2004 年植林前 調査では, 干潟 $\left(6.0 \mathrm{nMN}_{2} \mathrm{O} /\right.$ gwet $)$ よりも隣接するマン グローブ林 (8.2 nMN $\left.\mathrm{nM}_{2} \mathrm{O} / \mathrm{gwet}\right)$ のガス含有量が高い傾向 となった.さらに, 植林直後の 2005 年には, その傾向が 顕著となり干潟（11.3 $\mathrm{nMN}_{2} \mathrm{O} / \mathrm{gwet} ）$ と植林域（13.8 $\mathrm{nMN}_{2} \mathrm{O} / \mathrm{gwet}$ ) はほぼ同じ值であったが，隣接マングロー ブ林（21.5 nMN $2 \mathrm{O} /$ gwet）ではかなり高い值となった。し かしながら，2年後の 2007 年には実証植林域が隣接林よ りも高くなる傾向をみせた。一方, $\mathrm{CH}_{4}$ は植林 2 年後の みの調査ではあったが，干潟より実証試験地にて若干高 くなる傾向をみせ, 隣接するマングローブ林内がもっと も高くなり， $\mathrm{N}_{2} \mathrm{O}$ と同様の傾向であった。植林が間もな かったり密度の低かったりするマングローブ林では, 漁 師など人が多く通ることで, 堆積物表面が乱されている ことが多い. $\mathrm{CH}_{4} \cdot \mathrm{N}_{2} \mathrm{O}$ の発生条件となる嫌気的な部位 はすくないと考える. そのため, 干潟より植林エリアの ガス含有量が高くなり, 場合によっては隣接するマング ローブエリアへとガス含有量が増加する傾向にあること 推察される.

このような傾向は，例えばBauza（2005）が，プエル トリコのマングローブ林を対象に，林内から海側に側線 を設置し $\mathrm{N}_{2} \mathrm{O}$ 放出速度を観測している。 その結果, 林内 がもっとも高く $\left(0.53 \mu \mathrm{mol} \mathrm{N} \mathrm{O} \mathrm{m}^{-2} \mathrm{~h}^{-1}\right)$, 水際で最も低く なりその差は約 4 倍に達していた。 また，既報告（今村 ら，2002）の石垣島吹通川のマングローブ林においても， 河川淵付近よりも林内堆積物中の $\mathrm{N}_{2} \mathrm{O}$ ガス含有量が高か った.つまり, 今回の実証植林試験地における調査結果 においても, 前面干潟よりも成熟林の方が高い $\mathrm{CH}_{4}$ • $\mathrm{N}_{2} \mathrm{O}$ ガス含有量であったことは, 数すくない既存の文献 值と整合性があるといえる。

植林後数年は堆積物のトラップも少なく, 植林前の干 潟にほぼ近い様相でありぼらつきも大きい. 場所によっ
表-2 実証試験地のガス含有量 $\left(\mathrm{N}_{2} \mathrm{O}\right)$ (n：サンプル数)

\begin{tabular}{|c|c|c|c|c|c|}
\hline \multirow[b]{2}{*}{ location type } & \multirow[b]{2}{*}{ year } & \multirow[b]{2}{*}{$\mathrm{n}=$} & \multicolumn{3}{|c|}{$\begin{array}{l}\text { concentration of } \mathrm{N}_{2} \mathrm{O} \text { in wet } \\
\text { sediments }\left(\mathrm{nM} \mathrm{N} \mathrm{N}_{2} \mathrm{O} / \text { gwet }\right)\end{array}$} \\
\hline & & & $\max$. & $\min$. & ave. \\
\hline \multirow{4}{*}{ 干潟 } & 2004_Nov. & 3 & 8.3 & 4.3 & 6.0 \\
\hline & 2005_Apr. & 9 & 18.4 & 6.1 & 11.3 \\
\hline & 2007_June & 4 & 12.0 & 9.6 & 10.5 \\
\hline & total & 16 & 18.4 & 4.3 & $9.2 \pm 2.3$ \\
\hline \multirow{4}{*}{ 実証植林地 } & 2005_Apr. & 3 & 19.1 & 10.7 & 13.8 \\
\hline & 2006_June & 4 & 5.4 & 2.4 & 3.5 \\
\hline & 2007_June & 6 & 29.0 & 6.4 & 11.9 \\
\hline & total & 13 & 29.0 & 1.8 & $9.7 \pm 4.4$ \\
\hline \multirow{5}{*}{ 隣接林 } & 2004_Nov. & 3 & 9.0 & 7.8 & 8.2 \\
\hline & 2005_Apr. & 5 & 46.2 & 8.2 & 21.5 \\
\hline & 2006_June & 8 & 6.5 & 2.5 & 3.8 \\
\hline & 2007_June & 4 & 12.4 & 2.6 & 6.4 \\
\hline & total & 20 & 46.2 & 2.5 & $12.0 \pm 6.8$ \\
\hline
\end{tabular}

表-3 実証試験地のガス含有量 $\left(\mathrm{CH}_{4}\right)$ (n：サンプル数)

\begin{tabular}{c|c|c|c|c|c}
\hline \multicolumn{2}{c|}{} & \multicolumn{3}{|c}{$\begin{array}{r}\text { concentration of } \mathrm{CH}_{4} \text { in wet } \\
\left.\text { sediments(nM } \mathrm{CH}_{4} / \text { gwet }\right)\end{array}$} \\
\hline location type & year & $\mathrm{n}=$ & $\max$. & $\min$. & ave. \\
\hline 干潟 & 2007_June & 4 & 0.13 & 0.10 & 0.12 \\
\hline 実証植林地 & 2007_June & 6 & 0.28 & 0.16 & 0.22 \\
\hline 隣接林 & 2007_June & 4 & 1.07 & 0.27 & 0.58 \\
\hline
\end{tabular}

ては有機物等のトラップがあり負荷が高いと推測される 場所もあったが，今回の実証試験地における調査では， 周辺干潟と植林実証試験地との間には統計的な有意な差 は見られなかった。また，隣接する5〜9年経過してい るマングローブ林は密度も高く, 堆積物もトラップされ, $\mathrm{CH}_{4} \cdot \mathrm{N}_{2} \mathrm{O}$ が高くなる条件がそろっていたと考えられる.

このように，現地観測調査では植林開始年から数年は その堆積物環境に劇的な変化はなく $\mathrm{CH}_{4} \cdot \mathrm{N}_{2} \mathrm{O}$ ガス放出 も安定しない. しかしながら, その他温室効果ガスの放 出傾向には，マングローブの存在しない干潟よりも植林 実証試験地や隣接しているマングローブからのガス放出 速度が高くなる傾向を示しており，マングローブ林の成 熟が, 堆積物中からのその他温室効果ガスの放出速度を 増加させる可能性があることを示している.

\section{5. $\mathrm{CH}_{4} \cdot \mathrm{N}_{2} \mathrm{O}$ ガス放出によるマングローブ植林 炭素貯蔵量からの相殺量の推定}

今後マングローブ植林事業において，その他温暖化ガ スによる相殺量を評価するにあたり, 今回現地調査を行 つた植林実証試験地を対象に将来予測を行った.さらに, マングローブ林自身による炭素固定量と比較した.

マングローブ植林事業が実行される周辺環境が河口砂 州, ラグーン, 外洋, さらには流入負荷の影響を受けて 
いるような地点なのかによって, ベースライン值は大き く異なる，さらに，植林直後は植林による影響か否かを 評価することは難しい.

そこで，本項では以下の仮定条件をもとに，マングロ ーブ植林域における, $\mathrm{CH}_{4} \cdot \mathrm{N}_{2} \mathrm{O}$ ガス放出量の評価を行 った１）初期の植林地堆積物は不安的であるためガスの 放出速度は林齢7年目から積算する，2）植林密度は考慮 しない，3） GWP 值は IPCC 第 2 次評価報告書の值 $\left(\mathrm{CH}_{4}: 21 ， \mathrm{~N}_{2} \mathrm{O}: 310\right)$ を使用，4）ベースライン放出速度に ついて $\mathrm{N}_{2} \mathrm{O}$ は実証試験地の観測結果を $\mathrm{CH}_{4}$ は実測デー夕 の数が少ないので文献值を使用，5）林齢 7 年目以降のガ ス放出速度は現地観測の結果から得られた 5〜9年たった 隣接するマングローブ林にて実測した結果を用いる。

一方，堆積物中のガス含有量から放出速度を算出する 方法として, 水面からガス交換速度に準じ堆積物表面に おけるガス濃度と大気中のガス濃度の差にて放出される とした。また，水温（地温）・塩分の条件によって変化 するガス交換係数 $\left(k_{N 2 O}\right)$ については，以下の式より算 出した (Ledwell, 1984; Liss ら, 1986).

$$
k_{N 2 O}=k_{r e f}\left(\frac{S c_{N 2 O}}{S c_{r e f}}\right)^{n}
$$

ここで, $S c_{N 2 O}$ は水温と塩分で算出されるシュミット数, $S c_{r e f}=600$ で風速 $\mathrm{U} \leqq 3.6 \mathrm{~m} / \mathrm{s}$ の時 $\mathrm{n}=-0.5$; 風速 $\mathrm{U}>3.6$ $\mathrm{m} / \mathrm{s}$ の時 $\mathrm{n}=-0.67$ の関係をもつが，本調査では風速の情報 がないので無風とした.

最終的に，マングローブ林を植林したことによる， $\mathrm{CH}_{4} \cdot \mathrm{N}_{2} \mathrm{O}$ 放出に伴う炭素量相殺量の算出は, 植林後に 堆積物から放出されるガス放出速度から, ベースライン のガス放出速度を差し引いた值をもとに，対象植林面積 と炭素換算のための地球温暖化係数を乗じて算出した.

表-4に，放出量を算出するために用いた $\mathrm{CH}_{4}$ と $\mathrm{N}_{2} \mathrm{O}$ の 放出速度を示す。実証試地 $30 \mathrm{ha}$ からの温室効果ガスの 放出による相殺量（炭素換算）は，最大値を使用した場 合は, 植林面積の増加とともに単調に増加し, 年間約 620ton-C と試算された。一方，最小值の場合は，ほぼ0 であった。また，平均值を使用すると年間約 80 ton-C程 度であった。さらに，その平均值からべースライン值を 差し引いた試算では，約30ton-Cの炭素放出に相当する と試算された。仮定にあるように，林齢7年目（2011年） からこの值を使用すると，第一約束年の2012年までには 60ton-Cの相殺量となった. さらに，林齢 20 年の 2024 年 には420 ton-Cの実証試験地マングローブ林の $\mathrm{CO}_{2}$ 炭素隔 離量からの相殺量になる可能性があることが示された.

実証試験地マングローブ林による炭素貯蔵量の長期予 測結果（林齢 20 年）では，自己間引きモデル（成長に伴
表-4 相殺量計算に用いた各放出速度

\begin{tabular}{|c|c|c|c|}
\hline & & \multicolumn{2}{|c|}{$\begin{array}{c}\text { 放出速度の設定値 } \\
\left(\mu \mathrm{mol} \mathrm{m} \mathrm{m}^{-2} \mathrm{day}^{-1}\right)\end{array}$} \\
\hline & & $\mathrm{CH}_{4}$ & $\mathrm{~N}_{2} \mathrm{O}$ \\
\hline $\begin{array}{c}\text { 植林地全面の干潟 } \\
\text { (ベースライン) }\end{array}$ & & $1300^{\mathrm{a})}$ & 24.7 \\
\hline $\begin{array}{c}\text { 実証試験地のマングローブ林 } \\
\text { (初期1-2年) } \\
\end{array}$ & & $200^{\mathrm{b})}$ & 26.9 \\
\hline $\begin{array}{c}\text { 隣接マングローブ林 } \\
\quad(5 \text { 年〜9年 })\end{array}$ & $\begin{array}{l}\text { 最大值 } \\
\text { 平均值 }\end{array}$ & $\begin{array}{l}18400^{\mathrm{a})} \\
2200^{\mathrm{a}}\end{array}$ & $\begin{array}{r}181.7 \\
39.2\end{array}$ \\
\hline
\end{tabular}

a) 文献值, b) 実証試験地での観測結果より

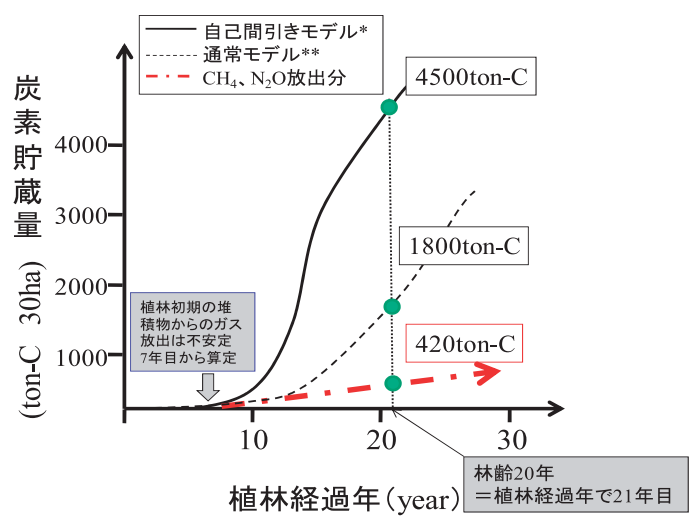

図-2 樹木炭素貯蔵量とその他温暖化ガスの関係 *：石井ら（2009）、**：立田ら（2009）

う林内の密度を考慮したモデル）を用いた場合（石井ら， 2009）で約 4500 ton-C，用いない場合（立田ら，2009） で約 1800 ton-Cであることから, 今回の $\mathrm{CH}_{4}$ と $\mathrm{N}_{2} \mathrm{O}$ ガス 発生による相殺分が，マングローブ林全体の炭素固定量 に対し 1 割〜2 割程度に達する可能性があることが示さ れた（図-2）。

前述したように，植林の候補地は干潟や河口砂州，さ らには養殖池とさまざまな環境条件が考えられ，個々の 現地観測から正確なガス発生量を調查することが重要で あるといえる。しかしながら，現地における観測条件を 整えることは難しく，今回のように堆積物ガス含有量か らガス放出速度を見積もる方法には仮定や誤差が含まれ るものの，堆積物がもつ $\mathrm{CH}_{4} \cdot \mathrm{N}_{2} \mathrm{O}$ 放出傾向を評価する ことができたと考える．長期的には植林したことによる 沿岸部での流動・堆積物の変化, それに伴う林内への有 機物量の変化も, 堆積物からの $\mathrm{CH}_{4} \cdot \mathrm{N}_{2} \mathrm{O}$ ガス放出量を 変化させる可能性もあり, 今後の課題として残る.

\section{6. まとめ}

マングローブ植林による正味の $\mathrm{CO}_{2}$ 固定量を正確に見 積るために重要な $\mathrm{CO}_{2}$ 以外のその他温室効果ガス $\left(\mathrm{CH}_{4} \cdot \mathrm{N}_{2} \mathrm{O}\right)$ の発生量について, 文献掞よび実証植林地 からのガス発生量を検討した。さらに，これらの結果を 
もとに，その他温室効果ガスによる放出量を推定した.

\section{(1) ベースラインとしての $\mathrm{CH}_{4} \cdot \mathrm{N}_{2} \mathrm{O}$ ガス放出速度}

マングローブのない沿岸・河川等から発生する $\mathrm{CH}_{4}$. $\mathrm{N}_{2} \mathrm{O}$ 放出速度について整理した。地域環境差（自然林・ 植林・高負荷等) によって $\mathrm{CH}_{4} \cdot \mathrm{N}_{2} \mathrm{O}$ の発生量には大き な幅があった。植林対象域における事前のベースライン 值の評価が必要であることがわかった。

\section{(2) 実証試験地からの $\mathrm{CH}_{4} \cdot \mathrm{N}_{2} \mathrm{O}$ ガス放出速度}

$\mathrm{CH}_{4}, \mathrm{~N}_{2} \mathrm{O}$ ともに調查時期に応じて若干のばらつきは あるものの, その平均值を比較すると, 植林前の干潟, 植林エリアさらには隣接するマングローブエリアへと ガス放出速度が増加する傾向にあることがわかった。 同一地点におけるこのような観測事例は少ないが，過 去の文献值と比較してもこの傾向は整合性がとれた結 果といえる.

\section{(3) $\mathrm{CH}_{4} \cdot \mathrm{N}_{2} \mathrm{O}$ ガス放出によるマングローブ植林炭素 貯蔵量からの相殺量の推定}

実証試験地に扔ける $\mathrm{CH}_{4} \cdot \mathrm{N}_{2} \mathrm{O}$ による炭素隔離量に対 する相殺分を推定した. 放出速度の算出には現地観測結 果を一部用いた。 その結果, $\mathrm{CH}_{4} \cdot \mathrm{N}_{2} \mathrm{O}$ による相殺量は, 平均で約 80 ton-C, ベースライン值を考慮すると, 約 30ton-C と見積もられた。この值は，実試験地に扔いて試 算されたマングローブ林による炭素貯蔵量に対し 1～2 割程度に達することがわかった。

本調査結果から，マングローブ植林によって土壤から の $\mathrm{CH}_{4} \cdot \mathrm{N}_{2} \mathrm{O}$ 放出量は少なからず増加することが明らか になった。今後, 小規模 $\mathrm{CDM}$ 方法論を進める上では, 土壤からの $\mathrm{CH}_{4} \cdot \mathrm{N}_{2} \mathrm{O}$ 放出量増加を考慮した植林面積の 設定や林の管理を実施する等の工夫が必要であると考え る. 今後の課題としては, 植林密度, 生長速度, 堆積物 の窒素・炭素循環の活性変化を考慮した経年的な調査観 測と時空間的な評価手法の開発が必要であるが，現状で は植林地点の環境条件にできるだけ合わせた值を使用 し，予測評価する方法が最善の策といえる，そのために も,さまざまな環境条件におけるその他温室効果ガス $\left(\mathrm{CH}_{4} \cdot \mathrm{N}_{2} \mathrm{O}\right)$ 放出に関して，十分なデー夕の蓄積および 調査が必要といえる.

\section{参 考 文 献}

石井 孝・立田 穣・今村正裕（2009）：自己間引きモデルを 用いたマングローブ植林地の炭素眝蔵量推定手法の開発, 電中研報告書 $\mathrm{Y} 08023$.

今村正裕・立田 穣・杉岡伸一（2002）：マングローブ水域と 林内堆積物に扔ける微量温暖化ガス $\left(\mathrm{N}_{2} \mathrm{O}\right)$ の挙動, 第 49 回海岸工学論文集, pp.1366-1370.

立田 穣・石井 孝・今村正裕（2009）：マングローブ植林実 証試験地に打ける $\mathrm{CO}_{2}$ 固定量評価 - 植林初期と長期間固 定量の予測 - ，電中研報告書 V08029.

林野庁 (2004)：小規模 CDM植林の簡素化されたルールにつ
いて，2004年12月 http://www.rinya.maff.go.jp/seisaku/cdm/ syokibo.html

Alongi, D.M., J. Pfitzner, L.A. Trott, F. Tirendi, P. Dixon and D.W. Klumpp (2005) : Rapid sediment accumulation and microbial mineralization in forests of the mangrove Kandelia candel in the Jiulongjiang Estuary, China, Estuarine, Coastal and Shelf Science, Volume 63, Issue 4, pp.605-618.

Bauza, J. (2005) : Emissions of greenhouse gases from mangrove forest sediments in Puerto Rico, Greenhouse gas and carbon balance in mangrove coastal ecosystem, edited Y. Tateda, Gendai Tosho Co.LTD, pp.165-178.

Eihner, M.J. (1990) : Nitrous oxide emission form fertilized soils: Summary of available data, J. Environmental Quality, vol.19, pp.272-280.

Ginani,I., Y.Bashan, G.Holguin and A. Strangmann (1996) : Characteristics and methanogenesis of the Balandra lagoon mangrove soils, Baja Calfornia Sur, Mexico,Geoderma, Vol.72, pp.149-160.

IPCC (2003) :LUCF Sector Good Practice Guidance, In IPCC Good Practice Guidance for LULUCF - Chapter 3, Jim Penman, Michael Gytarsky, Taka Hiraishi, Thelma Krug, Dina Kruger, Riitta Pipatti, Leandro Buendia, Kyoko Miwa, Todd Ngara, Kiyoto Tanabe and Fabian Wagner (Eds), the Institute for Global Environmental Strategies (IGES) for the IPCC, ISBN 488788-003-0.

IPCC Second Assessment Report (1995) : Climate Change 1995, The Science of Climate Change, J.T. Houghton, L.G. Meira Filho, B.A. Callender, N. Harris, A. Kattenberg and K. Maskell (Eds), Cambridge University Press, UK. 572.

Ledwell, J.J (1984) : The variation of gas transfer velocity with molecular diffusivity, In Gas Transfer at Water Surface, W.Brutsaert and G.Jirka (eds), pp.293-302.

Liss, P. S. and L. Merlivant (1986) : Air-sea gas exchange rates: introduction and synthesis, In the role of air-sea exchange in Geochemical cycling, pp.293- 302.

Mander, U., S. Teiter and J. Augustin, (2005) : Emission of greenhouse gases from constructed wetlands for wastewater treatment and from riparian buffer zones, Water Science \& Technology, Vol.52, No10-11, pp.167-176.

Michael K. (1994) : Soil-atmosphere exchange of nitrous oxide, nitric oxide, and methane under secondary succession of pasture to forest in the Atlantic lowlands of Costa Rica, Global Bio.Cyc.,Vol.8, No.4, pp.399-409.

Milton Muñoz-Hincapié, Julio M. Morell and Jorge E. Corredor (2002) : Increase of nitrous oxide flux to the atmosphere upon nitrogen addition to red mangroves sediments, Marine Pollution Bulletin, Vol.44, Issue 10, pp.992-996.

Mukhopadhyay, S.K., H.Biswas, T.K.De, B.K.Sen, S.Sen and Jana, T.K. (2002) : Impact of Sundarban mangrove biosphere on the carbon dioxide and methane mixing ratios at the NE Coast of bay of Bengal, India, Atmospheric Environmental, 36, pp.629-638.

Prieme, A. (1994) : Production and emission of methane in a brackish and a freshwater wetland, Soil Biol. Biochem., Vol.26, No.1, pp.7-18.

Seirzinger, S.P. (1998) : Global distribution of nitrous oxide production and $\mathrm{N}$ inputs in freshwater and coastal marine ecosystem, Global Biogeochemical cycles, Vol.12, No.1, pp.93113.

Tateda,Y (2005) : Greenhouse gas and carbon balance in mangrove coastal ecosystem, edited Y. Tateda, Gendai Tosho Co. LTD, ISBN978-4-906666-94-2. 